\title{
Utility of Pop-Up Satellite Archival Tags to Study the Summer Dispersal and Habitat Occupancy of Dolly Varden in Arctic Alaska
}

\author{
Michael B. Courtney, ${ }^{1,2}$ Brendan S. Scanlon, ${ }^{3}$ Audun H. Rikardsen ${ }^{4}$ and Andrew C. Seitz
}

(Received 9 March 2015; accepted in revised form 18 December 2015)

\begin{abstract}
In Arctic Alaska, Dolly Varden Salvelinus malma is highly valued as a subsistence fish; however, little is known about its marine ecology. New advances in electronic tagging, such as pop-up satellite archival tags (PSATs), provide scientists with a fishery-independent means of studying several aspects of this species' movement and ecology. To evaluate the usefulness of this technology, we attached 52 PSATs to Dolly Varden in the Wulik River, which flows from northwestern Alaska into the Chukchi Sea, to study several characteristics of the marine habits of this species. Overall, PSATs provided unprecedented information about summer dispersal of Dolly Varden, including the first evidence of offshore dispersal in the Chukchi Sea, as well as previously documented dispersal types such as movement to other rivers and southerly nearshore movements in northwestern Alaska. On the basis of minimal observable evidence of tag-induced behavioral effects, as well as movements of more than $450 \mathrm{~km}$ by fish at liberty (i.e., between tag deployment and release or recapture), we conclude that PSATs offer an effective alternative method for studying several aspects of Dolly Varden dispersal and ecology in areas where it is not practical or feasible to capture these fish, such as coastal and offshore regions of Arctic Alaska.
\end{abstract}

Key words: Chukchi Sea; dispersal; Dolly Varden; PSATs

RÉSUMÉ. Dans l'Alaska de l'Arctique, l'omble du Pacifique, Salvelinus malma revêt une grande importance en tant que poisson de subsistance. Toutefois, on en sait peu sur son écologie marine. Les progrès réalisés en matière de traçabilité électronique, notamment en ce qui a trait aux étiquettes de collecte de données par satellite (PSAT) permettent aux scientifiques d'étudier plusieurs aspects des déplacements et de l'écologie de cette espèce sans dépendre de la pêche. Afin d'évaluer l'utilité de cette technologie, nous avons fixé 52 PSAT à des ombles du Pacifique de la rivière Wulik, qui s'écoule depuis le nord-ouest de l'Alaska jusqu'à la mer des Tchouktches, pour étudier plusieurs caractéristiques des habitudes aquatiques de cette espèce. Dans l'ensemble, les PSAT ont permis de recueillir des renseignements sans précédent au sujet de la dispersion estivale de l'omble du Pacifique, y compris la première preuve de dispersion extracôtière dans la mer des Tchouktches et d'autres types de dispersion anciennement documentés, comme les déplacements vers d'autres cours d'eau et les déplacements sublittoraux en direction sud, dans le nord-ouest de l'Alaska. D'après un minimum d'éléments de preuve observables quant aux effets découlant de la présence d'étiquettes sur le comportement ainsi que d'après les déplacements de plus de 450 kilomètres des poissons en liberté (c'est-à-dire entre l'installation des étiquettes et le relâchement ou la recapture), nous concluons que les PSAT présentent une méthode de rechange efficace pour étudier plusieurs aspects de la dispersion et de l'écologie de l'omble du Pacifique dans des endroits où il n'est pas pratique ou réalisable de prendre ces poissons, comme dans les régions côtières et extracôtières de l'Alaska de l'Arctique.

Mots clés : mer des Tchouktches; dispersion; omble du Pacifique; PSAT

Traduit pour la revue Arctic par Nicole Giguère.

\section{INTRODUCTION}

Dolly Varden (Salvelinus malma) is found throughout a wide range in northwestern North America and northeastern Asia and is widely distributed in Alaska. While Dolly Varden is not commercially important in Arctic Alaska, it is thought to be the most frequently landed fish in many Arctic Alaska villages (Pedersen and Linn, 2005; Magdanz et al., 2010). For example, in the northwestern Alaskan villages of Kivalina and Noatak, the harvest of anadromous Dolly Varden in 2007 (30761 fish) far exceeded the harvest of all species of Pacific salmon Oncorhynchus spp. combined (5241 fish; Magdanz et al., 2010).

Because of the logistical challenges of capturing fishes in the Arctic Ocean, as well as the lack of commercial fisheries there, most research on Dolly Varden in Arctic Alaska has focused on its freshwater biology and ecology. For example, studies have attempted to locate spawning

\footnotetext{
${ }^{1}$ School of Fisheries and Ocean Sciences, University of Alaska Fairbanks, PO Box 757220, Fairbanks, Alaska 99775-7220, USA

${ }^{2}$ Corresponding author: mbcourtney@alaska.edu

${ }^{3}$ Alaska Department of Fish and Game, Sport Fish Division, 1300 College Road, Fairbanks, Alaska 99701-1551, USA

${ }^{4}$ Department of Arctic and Marine Biology, The Arctic University of Norway - UiT, N-9037 Tromsø, Norway

(C) The Arctic Institute of North America
} 
and overwintering sites, ascertain the timing of freshwater immigration and emigration, and identify the geographic distribution, mixing of stocks, and relative abundance of this species (Yoshihara, 1972; Furniss, 1975; Craig, 1977; McCart, 1980; DeCicco, 1985, 1989, 1996, 1997). In Arctic Alaska, beginning at two to five years of age, anadromous Dolly Varden start their annual migration to the ocean, where they feed each summer, returning to freshwater to overwinter (Armstrong and Morrow, 1980). After two or three marine migrations for summer feeding, Dolly Varden individuals reach maturity and return to their natal river to spawn in the fall (DeCicco, 1989). Additionally, results from conventional tagging and genetic studies show that Dolly Varden in Arctic Alaska demonstrate complex migration patterns, in which individuals may overwinter in mixed stocks and move across boundaries between Alaska, Canada, and the Russian Far East (DeCicco, 1992, 1997; Krueger et al., 1999; Crane et al., 2005). As a result, significant mixing of Dolly Varden stocks occurs in this area during both marine and freshwater phases, and subsistence fishers often target fish natal to multiple drainages.

Previous studies of the marine ecology of Dolly Varden suggested that the species remains in nearshore habitats while in the ocean (Armstrong and Morrow, 1980); however, several lines of evidence now suggest that Dolly Varden may occupy offshore habitats (DeCicco, 1992; Volkov et al., 1996; Fechhelm et al., 1997; Morita et al., 2009). For example, bycatch data from offshore Pacific salmon research fisheries south of the Bering Strait indicate that Dolly Varden is distributed throughout a wide range of the Pacific Ocean that includes nearshore and offshore waters of the Japan Sea, the Bering Sea, the Okhotsk Sea, and the Gulf of Alaska (Morita et. al., 2009). However, it is not known whether individuals occupy offshore areas of the Arctic Ocean because summer fisheries there are very limited. Fishery-independent data collection is therefore critically important for understanding the habits of Dolly Varden.

Electronic fish tags provide opportunities to examine aspects of marine biology and ecology of fishes, including marine dispersal, behavior, habitat occupancy, and mortality (Arnold and Dewar, 2001; Thorstad et al., 2014). One tag type, the pop-up satellite archival tag (PSAT), measures and records depth, temperature, and ambient light intensity while attached to a fish. On a pre-programmed date, the tag releases itself from the fish, floats to the surface of the ocean, and transmits the archived information to a series of ARGOS satellites, from which project investigators can retrieve it. Initially, PSATs were limited to largebodied marine species, including Atlantic bluefin tuna Thunnus thynnus (Block et al., 2005), white marlin Tetrapturus albidus (Horodysky et al., 2007), tiger sharks Galeocerdo cuvier (Holland et al., 2001), and Pacific halibut Hippoglossus stenolepis (Seitz et al., 2003), because of the large size and weight of tags. As the size of tags has become miniaturized, PSATs have been successfully used to describe habitat occupancy and movements of smaller fishes

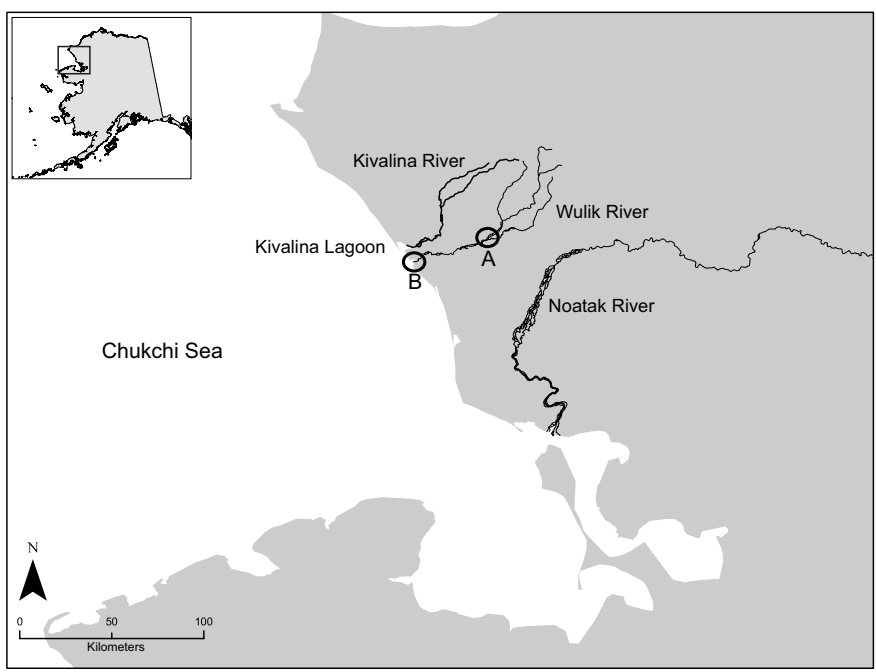

FIG. 1. Sampling locations (circles) where Dolly Varden were tagged in A) the Wulik River, Alaska, in 2012, and B) Kivalina Lagoon in 2013.

$(52-112 \mathrm{~cm})$ such as the striped bass Morone saxatilis (Graves et al., 2009) and Atlantic salmon Salmo salar (Chittenden et al., 2013a; Lacroix, 2013; Godfrey et al., 2015).

Because Dolly Varden in Arctic Alaska can attain sizes equivalent to those of striped bass and Atlantic salmon, we hypothesized that PSATs might be an effective tool for collecting fishery-independent information about the marine ecology of this species, including whether it occupies offshore areas of the Arctic Ocean. Since Dolly Varden is an important subsistence species for many Alaska Natives, this information is directly pertinent to future management decisions of Native fishers, as well as those of biological resource managers, mineral and energy developers, and regulators. This study therefore aims to evaluate the utility of using PSATs to study the distribution, dispersal, and habitat occupancy of Dolly Varden in the marine environment of Arctic Alaska. For this evaluation, we examined the following metrics: tag reporting rates and percentage of retrieved depth and temperature data; Dolly Varden summer distribution and dispersal patterns; and trends in behavior and survivorship of tagged Dolly Varden. Detailed analyses of depth and temperature data are not included in this paper, but can be found in a companion manuscript that describes the marine habitat occupancy and behaviors of Dolly Varden in nearshore and offshore waters of the Arctic Ocean (Courtney et al., 2015).

\section{METHODS}

\section{Study Site}

Fish were obtained from the Wulik River, located in

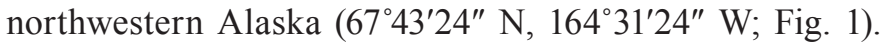
The Wulik River contains the largest known overwintering aggregation of Dolly Varden in Arctic Alaska; annual abundance estimates, produced by periodic aerial surveys 
from 1969 to 2008, are commonly more than 100000 fish (Scanlon, 2011). The Wulik River drainage is a clearwater system that drains a $2280 \mathrm{~km}^{2}$ watershed. Beginning at the Delong Mountains, the river flows westward approximately $145 \mathrm{~km}$ before entering the Chukchi Sea portion of the Arctic Ocean near the village of Kivalina, Alaska.

\section{Fish Capture}

In early to mid-June of 2012 and 2013, Dolly Varden that overwintered in the Wulik River were captured and tagged with PSATs $(n=52)$. In 2012, Dolly Varden $(n=20)$ were captured between 3 and 5 June using a beach seine $(70 \times$ $2.4 \mathrm{~m}$, with $0.05 \mathrm{~m}$ mesh) in the main stem of the Wulik River $\left(67^{\circ} 52^{\prime} 40.91^{\prime \prime} \mathrm{N}, 163^{\circ} 40^{\prime} 23.28^{\prime \prime} \mathrm{W}\right)$ approximately $45 \mathrm{~km}$ upstream from where it enters Kivalina Lagoon (Table 1; Fig. 1). In 2013, we captured Dolly Varden $(n=32)$ with gill nets in Kivalina Lagoon near the confluence of the lagoon and the Chukchi Sea $\left(67^{\circ} 43^{\prime} 24^{\prime \prime} \mathrm{N}\right.$, $164^{\circ} 31^{\prime} 24^{\prime \prime}$ W) on 13 and 14 June (Table 1; Fig. 1). This change was made to reduce the number of tagged fish incidentally captured in subsistence and recreational fisheries before leaving the Wulik River. When gill nets were deployed, we monitored them constantly, and upon capture of a Dolly Varden (indicated by bobbing floats), we removed the fish immediately from the gill net. Dolly Varden that had fork length greater than $60 \mathrm{~cm}$ (measured to the nearest $\mathrm{cm}$ ) and were deemed appropriate for tagging (i.e., no visible bleeding or injuries) were carefully removed from the nets with a knotless-mesh dip net and placed in a small-mesh holding pen $(1.2 \times 2.4 \mathrm{~m}, 70 \mathrm{~cm}$ water depth) . While fish were in the holding pen, we assessed their health for up to four hours before tagging. Each fish was monitored for signs of stress or abnormal behavior, including visual injuries and bleeding, loss of equilibrium, abnormal coloration, frayed fins, and rapid opercular movement. Only fish deemed to be healthy according to these metrics were tagged. After accumulating several large fish in the holding pen, we removed individuals one at a time. We placed each fish in a custom-made tagging cradle that contained river water, blindfolded it, and attached the PSAT tag.

\section{Tag Attachment}

Tags were attached to Dolly Varden using a "tag backpack" system formerly developed for Atlantic salmon (Chittenden et al., 2013a; Fig. 2). The backpack system included two components: the "straps" (a harness attachment system that was affixed through the dorsal musculature of the fish) and the "pack" (the transmitter, which was attached to the harness). The straps consisted of two custom-fabricated plastic plates (each one $1.0 \mathrm{~cm}$ wide $\times 5.0 \mathrm{~cm}$ long $\times 0.2 \mathrm{~cm}$ thick and protected on one side by a silicon pad $0.2 \mathrm{~cm}$ thick), which were affixed to both ends of a $15 \mathrm{~cm}$ length of $80 \mathrm{lb}$. test Dacron fishing line. The middle of this line was then secured to a corrodible link on the transmitter using a cow hitch knot. Each tag backpack was affixed to a fish by placing the silicon-padded side of each plastic bar approximately $2 \mathrm{~cm}$ below and on opposite sides of the dorsal fin. Once in place, the "tag backpack" was secured by threading a $20 \mathrm{~cm}$ long U-shaped piece of stainless steel wire first through two small holes in one of the plastic bars, then through the dorsal musculature of the fish, and finally out two small holes in the second plastic bar on the opposite side of the fish. The ends of the wire were secured to each other using a haywire twist, which was trimmed to a $1 \mathrm{~cm}$ tag-end and pushed to lie flat against the plastic bar to prevent detachment of the tag backpack. Each tagged fish was released near its capture site. All fieldwork was conducted under University of Alaska Fairbanks, Institution of Animal Care and Use Committee assurance \#308584 and State of Alaska Fisheries Research Permit SF-ECP-2007-87.

\section{PSAT Tag Specifications, Settings, and Data Acquisition}

Each PSAT tag (X-tag, Microwave Telemetry Inc.) weighed $40 \mathrm{~g}$ in air and was buoyant with the complete harness attached. While attached to a fish, the tag measured and recorded depth, temperature, and ambient light readings every two minutes (specifications available at http:// www.microwavetelemetry.com/fish/Xtag.cfm). The exact timing of return to freshwater was unknown, and the PSATs need to be in water with salinity of at least 5 psu for their release mechanism to function. We therefore used a staggered pop-up schedule, in which tags were programmed to pop up at two-week intervals (from 1 July to 1 September in 2012, and from 1 July to 1 October in 2013). This pop-up schedule was developed as a compromise between maximizing the duration of tag data records and maximizing the tag-reporting rate. Since we had no previous knowledge of the vertical range of Dolly Varden in marine waters, no constant depth release function to indicate mortality was activated on the PSATs.

On the predetermined dates, the tags released from the fish, floated to the surface of the sea, and transmitted archived temperature and depth data and daily sunrise and sunset times (based on light readings) via satellite. While the tag was transmitting, its location was determined from the Doppler shift of the transmitted radio frequency in successive uplinks received during one Argos satellite pass (Keating, 1995). Because of the large amount of data collected by the tags, limited data reception by Argos satellites, and short tag-battery life, only a subset of temperature and depth data, recorded at 15-minute intervals, was transmitted. However, if the tags were recovered while still attached to the fish (i.e., from fish recaptured in subsistence or sport fisheries), the complete data set recorded at twominute intervals was obtained. Daily sunrise and sunset times (calculated by PSATs) transmitted to satellites were sent to the tag manufacturer (Microwave Telemetry, Inc., Columbia, Maryland) and used to calculate daily geolocation estimates during post-processing of the raw data.

The end locations of tags were determined as follows. For tags that popped up and transmitted to satellites on 
TABLE 1. Deployment and end location information for pop-up satellite archival tags (PSATs) attached to 52 Dolly Varden in the Wulik River, Alaska, in June 2012 and in Kivalina Lagoon in 2013. End dates and locations represent when and where a fish reported to satellites or was physically recaptured. An asterisk $(*)$ denotes a fish that died prior to its pop-up date.

\begin{tabular}{|c|c|c|c|c|c|c|c|}
\hline Fish ID & $\begin{array}{l}\text { Length } \\
(\mathrm{cm})\end{array}$ & $\begin{array}{l}\text { Tagging location } \\
\text { and year }\end{array}$ & End date ${ }^{1}$ & $\begin{array}{c}\text { Time at } \\
\text { liberty (days) }\end{array}$ & $\begin{array}{c}\text { Minimum } \\
\text { distance }(\mathrm{km})\end{array}$ & $\begin{array}{c}\% \text { data } \\
\text { obtained }^{2}\end{array}$ & End location \\
\hline 107988 & 78 & Wulik 2012 & $7 / 1 / 12$ & 26 & 45 & 84 & Kivalina Lagoon \\
\hline 107989 & 76 & Wulik 2012 & $7 / 7 / 12$ & 32 & 13 & 100 & Wulik River \\
\hline 107990 & 82 & Wulik 2012 & $7 / 1 / 12$ & 26 & 319 & 100 & Russian Chukchi \\
\hline 107991 & 78 & Wulik 2012 & Failed & - & - & - & - \\
\hline 107992 & 81 & Wulik 2012 & $7 / 15 / 12$ & 40 & 383 & 100 & Russian Chukchi \\
\hline 107993* & 86 & Wulik 2012 & $7 / 4 / 12$ & 29 & 138 & 99 & Cape Espenberg \\
\hline 107994 & 82 & Wulik 2012 & Failed & - & - & - & - \\
\hline 107995 & 89 & Wulik 2012 & $7 / 4 / 12$ & 29 & 135 & 100 & Kotzebue Sound \\
\hline 107996 & 82 & Wulik 2012 & $7 / 12 / 12$ & 37 & 306 & 100 & Buckland River \\
\hline 107997 & 87 & Wulik 2012 & Failed & - & - & - & - \\
\hline 107998 & 86 & Wulik 2012 & $6 / 24 / 12$ & 19 & 0 & 100 & Wulik River \\
\hline 107999 & 92 & Wulik 2012 & $6 / 7 / 12$ & 2 & 0 & 100 & Wulik River \\
\hline 108000 & 82 & Wulik 2012 & $8 / 15 / 12$ & 71 & 381 & 98 & Russian Chukchi \\
\hline 108001 & 79 & Wulik 2012 & N.A.F & - & - & - & - \\
\hline 108002 & 76 & Wulik 2012 & $9 / 1 / 12$ & 88 & 38 & 1 & Wulik River \\
\hline 108003 & 85 & Wulik 2012 & $8 / 15 / 12$ & 71 & 359 & 97 & Russian Chukchi \\
\hline 108004* & 86 & Wulik 2012 & - & - & - & 96 & - \\
\hline 108005 & 79 & Wulik 2012 & $6 / 18 / 12$ & 13 & 45 & 100 & Kivalina Lagoon \\
\hline 108006 & 83 & Wulik 2012 & N.A.F & - & - & - & - \\
\hline $108007 *$ & 82 & Wulik 2012 & - & - & - & 54 & - \\
\hline 108030 & 69 & Kivalina 2013 & N.A.F & - & - & - & - \\
\hline 108031 & 65 & Kivalina 2013 & Failed & _- & _- & - & - \\
\hline 108032* & 64 & Kivalina 2013 & $6 / 26 / 13$ & 14 & 102 & 96 & Cape Espenberg \\
\hline 108033 & 66 & Kivalina 2013 & $6 / 22 / 13$ & 9 & 120 & 100 & Sheshalik Spit \\
\hline 108034* & 62 & Kivalina 2013 & $6 / 25 / 13$ & 13 & 38 & 84 & Coast \\
\hline 108035 & 71 & Kivalina 2013 & $7 / 25 / 13$ & 42 & 308 & 1 & Noatak River \\
\hline 108036 & 67 & Kivalina 2013 & $7 / 6 / 13$ & 24 & 390 & 100 & Russian Chukchi \\
\hline 108037 & 69 & Kivalina 2013 & $6 / 27 / 13$ & 14 & 140 & 99 & Noatak Delta \\
\hline 108038 & 72 & Kivalina 2013 & $7 / 15 / 13$ & 33 & 40 & 7 & Rabbit Creek \\
\hline 108039 & 65 & Kivalina 2013 & $7 / 15 / 13$ & 32 & 470 & 97 & Russian Chukchi \\
\hline 108040 & 68 & Kivalina 2013 & $7 / 10 / 13$ & 27 & 365 & 100 & Russian Chukchi \\
\hline 108041 & 83 & Kivalina 2013 & Failed & - & - & - & - \\
\hline 108042 & 79 & Kivalina 2013 & Failed & - & - & - & - \\
\hline 108043 & 79 & Kivalina 2013 & $6 / 16 / 13$ & 3 & 6 & 29 & Wulik River \\
\hline 108044 & 67 & Kivalina 2013 & N.A.F & - & - & - & - \\
\hline 108045 & 70 & Kivalina 2013 & N.A.F & _- & - & - & - \\
\hline 108046 & 79 & Kivalina 2013 & Failed & - & - & - & - \\
\hline 108047 & 76 & Kivalina 2013 & $8 / 21 / 13$ & 70 & 371 & 1 & Noatak River \\
\hline 108048 & 73 & Kivalina 2013 & $8 / 22 / 13$ & 70 & 70 & 9 & Omikviorok River \\
\hline 108223 & 72 & Kivalina 2013 & $9 / 3 / 13$ & 83 & 362 & 2 & Noatak River \\
\hline 108224 & 71 & Kivalina 2013 & Failed & - & - & - & - \\
\hline 108225 & 78 & Kivalina 2013 & Failed & - & - & - & - \\
\hline 108226 & 80 & Kivalina 2013 & $6 / 21 / 13$ & 8 & 120 & 100 & Sheshalik Spit \\
\hline 108227 & 72 & Kivalina 2013 & $6 / 21 / 13$ & 8 & 120 & 100 & Sheshalik Spit \\
\hline 108228 & 74 & Kivalina 2013 & Failed & - & - & - & - \\
\hline 108229 & 79 & Kivalina 2013 & N.A.F & - & - & - & - \\
\hline 108230 & 83 & Kivalina 2013 & $9 / 3 / 13$ & 83 & 362 & 54 & Noatak River \\
\hline 108231 & 68 & Kivalina 2013 & $6 / 16 / 13$ & 3 & 4 & 58 & Wulik River \\
\hline 108232 & 76 & Kivalina 2013 & $9 / 15 / 13$ & 94 & 228 & 3 & Noatak River \\
\hline 108233* & 81 & Kivalina 2013 & - & - & - & 82 & - \\
\hline 108234 & 72 & Kivalina 2013 & $10 / 17 / 13$ & 127 & 45 & 4 & Wulik River \\
\hline 129838 & 78 & Kivalina 2013 & $7 / 27 / 13$ & 44 & 191 & 17 & Noatak River \\
\hline
\end{tabular}

1 "N.A.F" (not accounted for) refers to tags that never reported to satellites or were recaptured in fisheries, and "Failed" refers to tags that transmitted, but did not provide end location estimates.

${ }^{2}$ Total number of individual depth and temperature readings received via Argos, divided by the number of readings that should have been transmitted and received by satellites.

their scheduled transmission date $(n=17)$, we used the location of the first transmission (Argos location class 1, 2, or 3; positional error $<1.5 \mathrm{~km}$ ). For tags that prematurely released from a tagged fish within 10 days before their scheduled transmission date $(\mathrm{n}=3)$, we back-calculated end locations by estimating and subtracting the distance the tag traveled while drifting on the ocean surface between its premature release and the location of its first transmission to satellites (Chittenden et al., 2013a). For tags $(n=4)$ that prematurely released in freshwater, we assumed (on the 


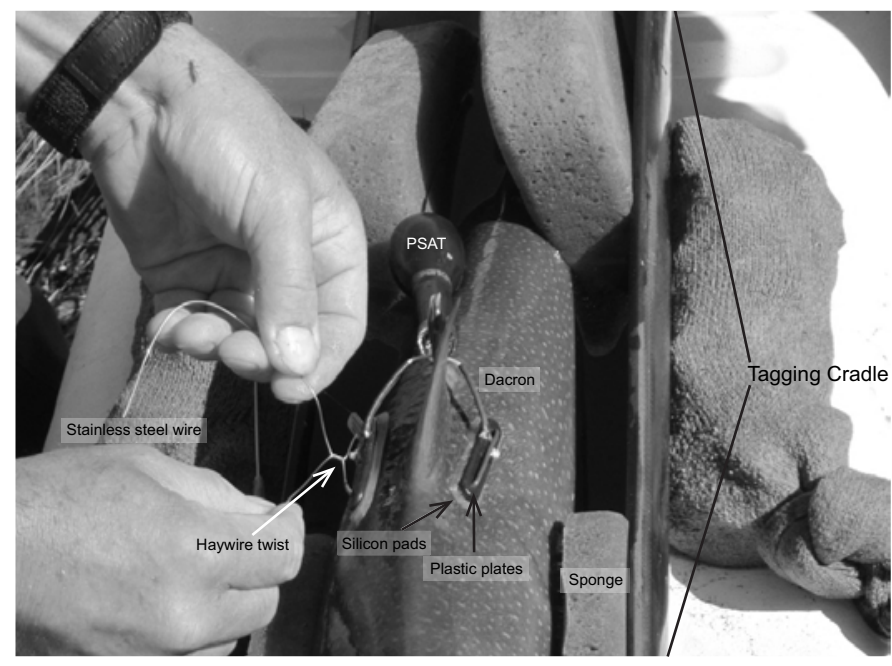

FIG. 2. An X-tag attached to a Dolly Varden with a wire harness "tag backpack" attachment system.

basis of a cyclic temperature range wider than that found in adjacent ambient water) that the tag had washed up on land near the release point (LaCroix, 2013); we assigned the position of the first transmission as the end location. Tagged fish recaptured in subsistence and sport fisheries $(\mathrm{n}=9)$ were assigned Global Positioning System (GPS) end locations (positional error $<0.2 \mathrm{~km}$ ) as reported by fishers.

Marine mortality of fish was assumed if tags had depth readings indicating that the fish had sunk to the bottom of the sea floor $(15-50 \mathrm{~m})$ and remained at that constant depth for at least three days $(n=6)$. The first tag transmission with a Class 1-3 Argos location was considered the end location for fish presumed to be deceased if depth and temperature records indicated that tag drift (physical movement of the tag) before the tag reported to satellites was negligible (LaCroix, 2013). In all other cases (assumed tag-drift, $n=$ 3 ), end locations were excluded from dispersal analyses.

\section{Data Analyses}

We analyzed the metrics examined as follows. The tag reporting rate was determined by tabulating the percentage of tags for which end locations could be determined (through reports to Argos or reports from fishers who recaptured tagged fish). The percentage of retrieved depth and temperature data was calculated as the total number of individual depth and temperature readings received via Argos, divided by the number of readings that should have been transmitted and received by satellites, assuming that depth and temperature data subsets (collected every 15 minutes) were transmitted. Additionally, the reporting rate and percent data retrieved from tags were qualitatively compared to time at liberty and end location habitat type (riverine, lagoon, or marine).

We determined the summer distribution and dispersal patterns of tagged Dolly Varden by examining minimum dispersal distance, end locations, and daily geolocation estimates. Minimum dispersal distance traveled was calculated by measuring the great arc circle distance of a nonmeandering route that did not pass over land between tagging and end locations. We used minimum distance traveled to examine dispersal distance because the uncertainty of individual fish tracks prevented calculation of the actual or maximum distance traveled (see Results). Distribution and dispersal patterns were qualitatively described by examining end locations for each two-week period in a geographical information system (GIS) framework. In addition, we assessed the efficacy of light-based geolocation by tabulating the number of tags and the total number of days for which sunrise and sunset could be calculated to subsequently produce daily geolocation estimates. However, given the failure of most tags to provide daily geolocation estimates (see Results), the relatively large errors associated with light-based geolocation, and the short time at liberty ( $<90$ days), we did not use alternative models based on lightbased geolocations, (e.g., State-space Kalman filters; Sibert et al., 2003; Lam et al., 2008) to produce the most probable tracks of tagged fish. Instead, we developed a simple filtering method to examine the plausibility of daily locations. We defined plausible daily geolocations as locations within a body of water (i.e., not on land) where daily tag-recorded seasurface temperatures (SSTs; i.e., tag-recorded temperature $<2 \mathrm{~m}$ ) were within $\pm 1^{\circ} \mathrm{C}$ of satellite-derived SSTs (National Oceanic and Atmospheric Administration, Geo-Polar Blended SST Analysis $0.05^{\circ} \times 0.05^{\circ}$ ). We used the plausibility of daily locations to examine the utility of light-based geolocation qualitatively.

Two analyses were conducted to examine dispersal distance and survivorship of tagged Dolly Varden. First, we compared the size of fish who died, fish that were alive on the pop-up date, fish that failed to provide an end location, and fish that were not accounted for (never reported to satellites or recaptured in fisheries), using means and bootstrapped (1000 replications) 95\% confidence intervals. Second, we used a linear model $(\alpha=0.05)$ to examine the relationship between fork length and the square root of minimum dispersal distance $(\mathrm{km})$. A transformation (square root) was used on the response variable in order to meet the statistical assumptions of linear regression (i.e., that errors are normally and identically distributed). All statistical tests were performed with the statistical software $\mathrm{R}$ (R Core Team, 2014).

\section{RESULTS}

\section{Reporting Rates}

Tagged Dolly Varden ranged from 62 to $92 \mathrm{~cm}$ in length $(77 \pm 7 \mathrm{~cm}$, mean $\pm \mathrm{SD})$ and were at liberty for 2 to 127 days (Table 1). Of the 52 tags deployed, 33 (63\%) provided end locations used in the dispersal analyses. Specifically, $24(46 \%)$ provided end locations calculated by Argos satellites, and nine tags (17\%) recovered while still attached to fish in subsistence and recreational fisheries provided GPS 
TABLE 2. Summary of annual deployment of pop-up satellite archival tags attached to Dolly Varden in the Wulik River and Kivalina Lagoon, Alaska.

\begin{tabular}{|c|c|c|c|c|c|c|}
\hline Year & Tagged $^{1}$ & Recaptured $^{2}$ & Argos end locations ${ }^{3}$ & Failed end locations 4 & Not accounted for ${ }^{5}$ & Mortality $^{6}$ \\
\hline 2012 & 20 & $6(30 \%)$ & $7(35 \%)$ & $3(15 \%)$ & $2(10 \%)$ & $3(15 \%)$ \\
\hline 2013 & 32 & $3(9.4 \%)$ & $17(53 \%)$ & $7(22 \%)$ & $4(13 \%)$ & $3(9.4 \%)$ \\
\hline Total & 52 & $9(17 \%)$ & $24(46 \%)$ & $10(19 \%)$ & $6(12 \%)$ & $6(12 \%)$ \\
\hline
\end{tabular}

${ }^{1}$ Number of fish tagged.

${ }^{2}$ Tagged fish recaptured in sport and subsistence fisheries.

${ }^{3}$ Tags that provided end locations determined by Argos satellites.

${ }^{4}$ Tags that reported to satellites, but failed to provide end locations.

${ }^{5}$ Tags that neither transmitted nor were recaptured.

${ }^{6}$ Fish that presumably died before the tag's scheduled pop-up date.

end locations (Table 2). The fates of the remaining 19 tags (37\%) were as follows: 10 tags (19\%) transmitted, but failed to provide any end locations; three tags $(6 \%)$ prematurely released after death of the fish and drifted for 1-2 months; therefore, their subsequent end locations were not used; and six tags (12\%) never reported and could not be accounted for (Table 2).

\section{Percentage of Retrieved Data}

The percentage of archived temperature and depth data received from tags that transmitted to satellites varied from $0 \%$ to $100 \%$ (Table 1; Fig. 3). Most tags attached to fish that reported from freshwater provided end locations, but failed to provide any substantial archived temperature and depth data $(0 \%-1 \%)$; the exceptions were tags of four fish that presumably washed up on land, reported from freshwater rivers, and provided $17 \%-58 \%$ of their archived data (Table 1; Fig. 3). In contrast, fish tags that reported from the ocean provided $84 \%-100 \%$ of the subset of archived data recorded at 15 -minute intervals, and tags that were recaptured provided $100 \%$ of archived data recorded at twominute intervals (Table 1; Fig. 3). While tags reporting from freshwater and from saltwater differed greatly in the percentage of data retrieved, little correlation was observed between time at liberty and the percentage of data retrieved (Fig. 3).

\section{Summer Distribution and Dispersal Patterns}

Tagged Dolly Varden had end locations in both marine $(\mathrm{n}=15)$ and freshwater $(\mathrm{n}=18)$ habitats and dispersed a mean minimum distance ( \pm SD) of $206 \pm 162 \mathrm{~km}$ (range $0-470 \mathrm{~km}$; Table 1). Of the tags with end locations in marine habitats, seven reported from the Russian Chukchi Sea approximately $100-200 \mathrm{~km}$ north of the Chukotka Peninsula, exhibiting minimum travel distances from the tagging locations of $319-470 \mathrm{~km}$ (Table 1; Fig. 4). Eight other tags had end locations in nearshore marine waters adjacent to Kotzebue Sound, 40-135 km southwest of the tagging locations (Table 1; Fig. 4). Of the tags with freshwater end locations, nine reported from locations in other river drainages, including the Omikviorok, Rabbit, Buckland, and Noatak drainages in northwestern Alaska, 40-362 km distant from the tagging sites (Table 1; Fig. 4). The other tagged fish with freshwater end locations showed less extensive dispersal, and their tags had end locations in Kivalina Lagoon $(\mathrm{n}=2)$ and in the lower and upper reaches of the Wulik River, near known overwintering and spawning areas $(\mathrm{n}=7$ ) (Table 1; Fig. 4). We examined end locations in two-week intervals. In early to late June, fish were located near the tagging sites (mouth and lower reaches of the Wulik River) and in nearshore areas within or adjacent to Kotzebue Sound (Fig. 5). From early July to September, some fish still occupied the Wulik River; however, tagged fish were more widely distributed, with locations in the Chukchi Sea north of Russia, near Kotzebue Sound, and in other rivers (Fig. 5).

In addition to end locations, 10 PSATs (19\%) provided limited daily light-based geolocation estimates. Daily geolocation estimates were calculated for a total of 30 days: 14 days in June, one day in July, and 15 days in August. The geolocation estimates provided in June and July (15 days from 10 PSATs) varied widely. None of these locations were validated as plausible, since 14 were on land and one had a daily corresponding sea surface temperature that was $1^{\circ} \mathrm{C}$ or more higher than the satellite-derived SST in the same location. In August, two tags provided daily geolocation estimates ( $\mathrm{n}=15 \mathrm{~d}, 6-14$ August 2012) and reported just days later (on 15 August 2012) in the Russian Chukchi Sea. Of these daily estimates, two were on land; however, the other 13 had daily corresponding SSTs that were within $\pm 1^{\circ} \mathrm{C}$ of satellite-derived SST and thus were considered plausible. All 13 were broadly distributed in the Chukchi Sea in the vicinity $(106 \pm 55 \mathrm{~km}$, mean $\pm \mathrm{SD})$ of their respective end locations. For the remaining tags $(n=42)$, the light sensor was unable to distinguish any diel differences in light intensity, which precluded identification of sunrise and sunset events and subsequent calculation of daily geolocation estimates.

\section{Trends in Dispersal Distance and Survivorship}

Mortality was observed in fish ranging in length from 62 to $86 \mathrm{~cm}$, which spanned nearly the entire range of fish 


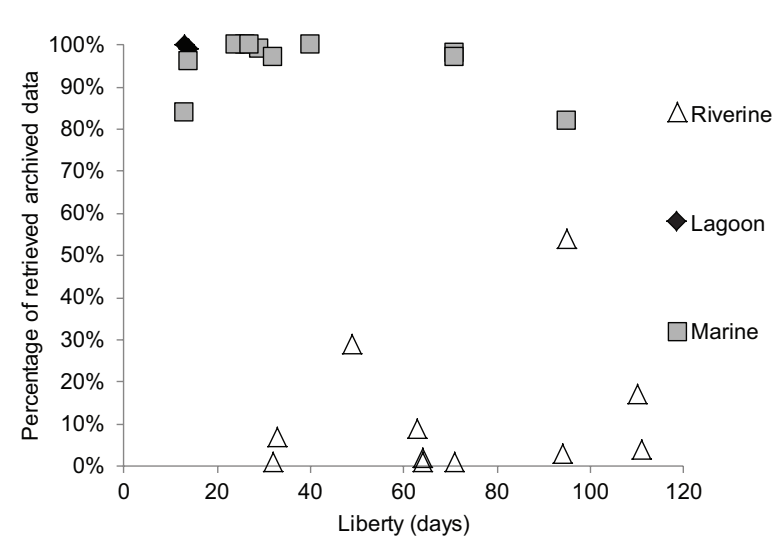

FIG. 3. Percentage of retrieved data (total number of individual depth and temperature readings received via Argos divided by the number of readings that should have been transmitted and received) compared to time at liberty (days) for fish with tags that reported to Argos satellites from three habitat types.

tagged in this study $(\mathrm{n}=6$; Tables 1 and 2). Fish size did not appear to relate to whether a fish was alive or dead on its pop-up date, as mean sizes of live and deceased fish differed only slightly (Fig. 6). A similar lack of relationship was found between mean length and minimum distance traveled $(p>0.05)$.

\section{DISCUSSION}

PSATs offer an effective alternative method with which to study several aspects of large adult Dolly Varden behavior and habitat occupancy in locations where it is not economically or logistically practical or even feasible to recapture fish, such as coastal and offshore regions of the Arctic. While attached to Dolly Varden, PSATs provided unprecedented information about their dispersal patterns in Arctic Alaska, including the first evidence of offshore habitat occupation in the Arctic Ocean.

The overall reporting rate of $63 \%$ (from Argos and recaptures) in this study was lower than reporting rates analyzed in a review of other PSAT tagging studies (grand mean $79 \%$; $95 \% \mathrm{CI}=76 \%$ to $82 \%$ ), in which 731 tags were deployed on 19 species of marine animals (Musyl et al., 2011). This relatively low reporting rate is most likely attributable to the location of tagged Dolly Varden in freshwater on their pop-up dates. Given that the PSATs used in this study require 5 psu of salinity for the release mechanism to function properly, occupation of freshwater likely led to some failure of the release mechanism. Some tags did report from freshwater, but it is likely that instead of releasing from the fish, the tags were still attached to the fish. We surmise that while tags were attached to the fish, the antennae periodically protruded above the surface of the water and intermittently transmitted to satellites, thus providing sporadic transmissions that resulted in relatively few end locations and low data recovery rates. This claim is supported by the tags that presumably washed up on shore near

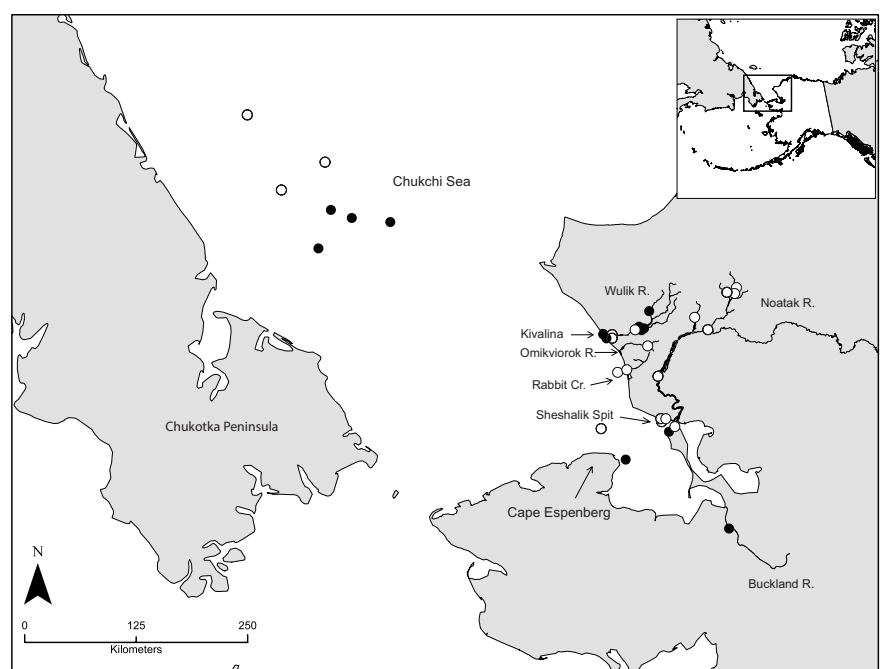

FIG. 4. End locations of Dolly Varden with pop-up satellite archival tags deployed in the Wulik River, Alaska, in 2012 (black dots) and in Kivalina Lagoon in 2013 (white dots). End locations indicate where the tag transmitted to satellites or the fish was physically recaptured.

freshwater. While these tags still had lower data retrieval rates compared to tags that reported from marine waters, they provided substantially more data $(17 \%-58 \%$ of their archived data) than the tags that reported from freshwater rivers. While the reasons that tags washed up on shore and reported from land adjacent to freshwater are unknown, possible explanations include predation by birds and mammals or tag shedding.

While occupation of freshwater lowered the tag reporting and data recovery rates, PSATs that reported from marine waters provided informative end locations. Some of the tagged fish in this study demonstrated movement patterns similar to those previously described for Dolly Varden in northwestern Alaska (reviewed in DeCicco, 1997), including movements to other rivers and southerly marine nearshore movements. However, several PSATs in this study provided the first documentation of a northwesterly offshore dispersal in the Russian Chukchi Sea. It is likely that previous studies did not document offshore dispersal in the Arctic Ocean because there were no fisheries in that region and therefore no feasible method for recovering tagged fish. Our new data underscore the importance of using technology that does not rely on the physical recapture of tagged fish.

The dearth of geolocation estimates in this study is likely due to the inability of the X-tag to detect changes in ambient irradiance during the Arctic summer, when the sun does not set in our study area from mid-May to mid-July, thus preventing the calculation of light-based geolocation estimates on most days. Even when tags provided limited daily geolocation estimates, most derived location estimates were not plausible until the middle of August, when there were approximately seven hours between sunset and sunrise events. Given that Dolly Varden spend only a short time (up to three months) in the ocean each summer before returning to freshwater, the method of light-based geolocation used in 


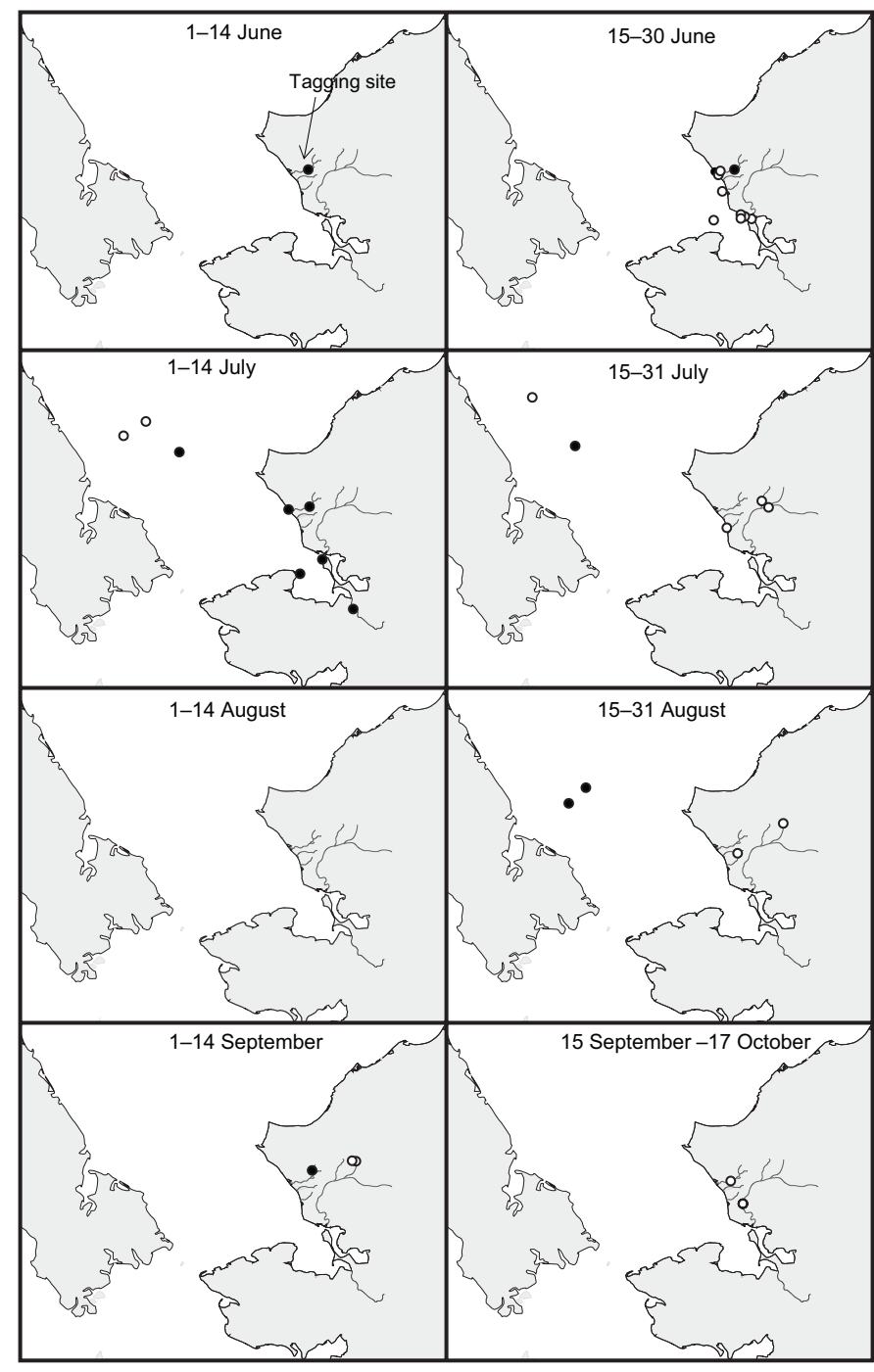

FIG. 5. End locations of Dolly Varden with pop-up satellite archival tags throughout the summers of 2012 (black dots) and 2013 (white dots). End locations indicate where the tag transmitted to satellites or the fish was physically recaptured.

this study does not appear to be effective for understanding the most probable tracks of fish occupying the Arctic Ocean during the summer. However, alternative location estimation models based on tag-recorded depth and temperatures may have the potential to provide valuable insights into the spatial and temporal distribution of Dolly Varden during the summer (Hayes et al., 2011; Chittenden et al., 2013a, b; Courtney et al., 2015).

Because there were no observed relationships between fish size, mortality, and dispersal patterns, PSATs appeared to have relatively little effect on the health and swimming ability of tagged Dolly Varden at least $60 \mathrm{~cm}$ long. Specifically, while at liberty for up to 126 days, tagged Dolly Varden traveled up to $470 \mathrm{~km}$ and transited at speeds up to $60 \mathrm{~km} \cdot$ day $^{-1}$ (Courtney et al., 2015), suggesting that the tag did not adversely affect the swimming ability of tagged fish. These results suggest that $60 \mathrm{~cm}$ is likely an appropriate guideline for minimum PSAT tagging size of Dolly Varden. This guideline is similar to that for another salmonid

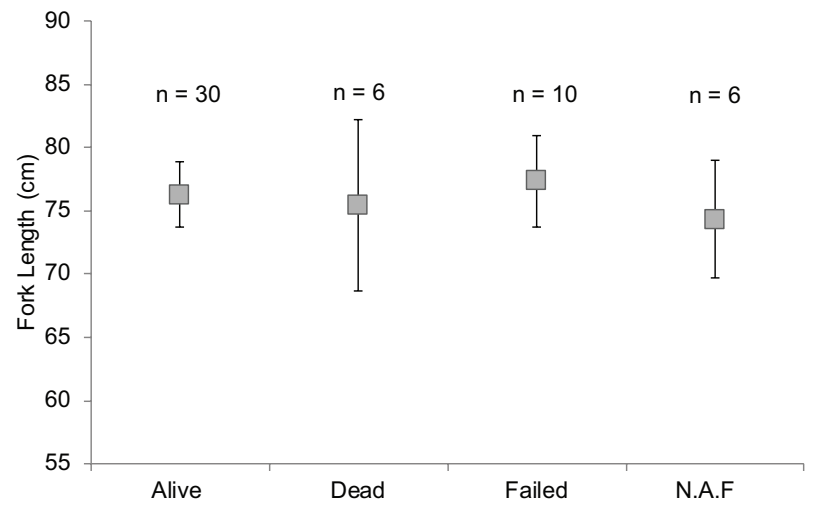

FIG. 6. Relation of fish length to fate of the fish and tag (based on archived data). Mean fork lengths (bootstrapped 95\% confidence intervals) for Dolly Varden that were alive on the scheduled pop-up date, those dead on that date, those whose tags failed to transmit an end location, and those that were not accounted for.

species, the Atlantic salmon; individuals as small as $52 \mathrm{~cm}$ have been tagged and tracked with the same PSAT (Lacroix, 2013). However, because our study used a small sample and a design lacking control groups, a precise minimum size guideline is not known. Future laboratory studies of the physiological effects of PSAT tagging on salmonids would help to define this guideline.

Interpreting mortality events in this study is difficult because it is challenging to distinguish natural mortality from tag-induced mortality. While little is known about its causes and rates, natural mortality of Dolly Varden from Arctic Alaska is thought to be highly variable and dependent on environmental conditions (Arvey, 1991). Past research has suggested that birds and marine mammals, particularly spotted seals Phoca largha, may cause significant mortality of Dolly Varden in northwestern Alaska in some years (DeCicco, 1985, 1996). Although the specific cause of fish mortality in this study is unknown, most of the identified mortality events (five out of six) occurred in nearshore areas where marine mammals are common, suggesting that predation is the cause, as has been documented for Atlantic salmon (Lacroix, 2014).

The pop-up schedule used in this study, while successful for ensuring that some fish would be in marine waters on the pop-up date and thus properly release and transmit data, could be refined in future studies. The results from this study suggest that scheduling pop-up dates between 15 July and 15 August will likely maximize the probability of retrieving data in future experiments on Dolly Varden in northwestern Alaska. Therefore, future PSAT tagging studies on Dolly Varden and other anadromous species should take into account the population-specific knowledge about the biology, ecology, and life history of the study species, to maximize data retrieved. Additionally, an alternative technology that does not rely on a galvanic corrosion release mechanism (and thus would allow for freshwater release) would be invaluable for studying anadromous fishes and would allow researchers to obtain more data during the entire ice-free season. 
Natural resource development, which is currently occurring in both offshore and nearshore areas of the Arctic Ocean, may present challenges for fish communities, including Dolly Varden. In the future, monitoring and understanding interactions between fish and these anthropogenic activities will be directly pertinent to assessing a species' vulnerability. PSATs could offer an effective alternative method for expanding our knowledge of a species' distribution and habitat use, as well as its potential interactions with current and future anthropogenic activities.

\section{ACKNOWLEDGMENTS}

The authors wish to thank Mark Evans, Matt Evenson, Tom Taube, Chris Eckert, Rebecca Hager, Wayne Hall, the employees and contractors of Red Dog Mine, and the residents of Kivalina, Alaska, for their valuable support during fieldwork. Additionally, we thank Chris Zimmerman for providing helpful comments on the manuscript. Project funding was provided by the Environmental Studies Program, Bureau of Ocean Energy Management, U.S. Department of Interior, through the University of Alaska Fairbanks Coastal Marine Institute, the Red Dog Mine operated by Teck, Inc., the Alaska Department of Fish and Game, and the University of Alaska Fairbanks School of Fisheries and Ocean Sciences. Student funding for Michael Courtney was provided by the Rasmuson Fisheries Research Center, the Pollock Conservation Cooperative Research Center, and the University of Alaska Fairbanks Undergraduate Research and Scholarly Activity program.

\section{REFERENCES}

Armstrong, R.H., and Morrow, J.E. 1980. The Dolly Varden char, Salvelinus malma. In: Balon, E.K., ed. Charrs: Salmonid fishes of the genus Salvelinus. The Hague, The Netherlands: Dr. W. Junk Publishers. 99-140.

Arnold, G.P., and Dewar, H. 2001. Electronic tags in marine fisheries research: A 30-year perspective. In: Sibert, J.R., and Nielsen J.L., eds. Electronic tagging and tracking in marine fisheries. Dordrecht, The Netherlands: Kluwer Academic Publishers. 7-64.

http://dx.doi.org/10.1007/978-94-017-1402-0_2

Arvey, W.D. 1991. Stock status of anadromous Dolly Varden in waters of Alaska's North Slope. Fishery Manuscript No. 91-3. Anchorage: Alaska Department of Fish and Game, Division of Sport Fish.

Block, B.A., Teo, S.L.H., Walli, A., Boustany, A., Stokesbury, M.J.W., Farwell, C.J., Weng, K.C., Dewar, H., and Williams, T.D. 2005. Electronic tagging and population structure of Atlantic Bluefin tuna. Nature 434:1121 - 1127.

http://dx.doi.org/10.1038/nature03463
Chittenden, C.M., Adlandsvik, B., Pedersen, O.-P., Righton, D., and Rikardsen, A.H. 2103a. Testing a model to track fish migrations in polar regions using pop-up satellite archival tags. Fisheries Oceanography 22(1):1-13.

http://dx.doi.org/10.1111/fog.12000

Chittenden, C.M., Fauchald, P., and Rikardsen, A.H. 2013 b. Important open-ocean areas for northern Atlantic salmon (Salmo salar) —as estimated using a simple ambienttemperature approach. Canadian Journal of Fisheries and Aquatic Sciences 70(1):101-104. http://dx.doi.org/10.1139/cjfas-2012-0215

Craig, P.C. 1977. Ecological studies of anadromous and resident populations of Arctic char in the Canning River drainage and adjacent coastal waters of the Beaufort Sea, Alaska. Arctic Gas Biological Report Series 41. 119 p.

Crane, P., DeCicco, F., Spearman, B., and Wenburg, J. 2005. Genetic diversity of Dolly Varden populations in Norton and Kotzebue Sounds. Alaska Fisheries Technical Report No. 80. Anchorage: U.S. Fish and Wildlife Service.

Courtney, M.B., Scanlon, B.S., Rikardsen, A.H., and Seitz, A.C. 2015. Marine behavior and dispersal of an important subsistence fish in Arctic Alaska, the Dolly Varden. Environmental Biology of Fishes. Published online 11 December 2015. http://dx.doi.org/10.1007/s10641-015-0468-3

DeCicco, A.L. 1985. Inventory and cataloging of sport fish and sport fish waters of western Alaska with emphasis on Arctic char life history studies. Annual Performance Report. Federal Aid in Fish Restoration Vol. 26. Juneau: Alaska Department of Fish and Game.

- 1989. Movements and spawning of adult Dolly Varden char (S. malma) in Chukchi Sea drainages of northwestern Alaska: Evidence for summer and fall spawning populations. Physiology and Ecology Japan, Special Vol. 1:229-238. 1992. Long-distance movements of anadromous Dolly Varden between Alaska and the U.S.S.R. Arctic 45(2):120 - 123. http://dx.doi.org/10.14430/arctic1382

. 1996. Abundance of Dolly Varden overwintering in the Wulik River, northwestern Alaska, during 1994/1995. Fishery Data Series No. 96-3. Anchorage: Alaska Department of Fish and Game, Division of Sport Fish.

1997. Movements of postsmolt anadromous Dolly Varden in northwestern Alaska. In: Reynolds, J.B., ed. Fish ecology in Arctic North America. Bethesda, Maryland: American Fisheries Society. 175-183.

Fechhelm, R.G., Bryan, J.D., Griffiths, W.B., and Martin, L.R. 1997. Summer growth patterns of northern Dolly Varden (Salvelinus malma) smolts from the Prudhoe Bay region, Alaska. Canadian Journal of Fisheries and Aquatic Sciences 54(5):1103-1110.

http://dx.doi.org/10.1139/f97-022

Furniss, R.A. 1975. Study G-I-I: Inventory and cataloging of the Arctic area waters. Annual Report of Performance, Project F-9-7, Federal Aid in Fish Restoration Vol. 16. Juneau: Alaska Department of Fish and Game, Division of Sport Fish. 
Godfrey, J.D., Stewart, D.C., Middlemas, S.J., and Armstrong, J.D. 2015. Depth use and migratory behaviour of homing Atlantic salmon (Salmo salar) in Scottish coastal waters. ICES Journal of Marine Science 72(2):568-575.

http://dx.doi.org/10.1093/icesjms/fsu118

Graves, J.E., Horodysky, A.Z., and Latour, R.J. 2009. Use of pop-up satellite archival tag technology to study postrelease survival of and habitat use by estuarine and coastal fishes: An application to striped bass (Morone saxatilis). Fishery Bulletin 107:373-383.

Hayes, S.A., Bond, M.H., Wells, B.K., Hanson, C.V., Jones, A.W., and MacFarlane, R.B. 2012. Using archival tags to infer habitat use of central California steelhead and coho salmon. In: McKenzie, J., Parsons, B., Seitz, A.C., Kopf, R.K., Mesa, M., and Phelps, Q., eds. Advances in fish tagging and marking technology. AFS Symposium 76. Bethesda, Maryland: American Fisheries Society. 471-492.

Holland, K.N., Bush, A., Meyer, C.G., Kajiura, S., Wetherbee, B.M., and Lowe, C.G. 2001. Five tags applied to a single species in a single location: The tiger shark experience. In: Sibert, J.R., and Nielsen, J.L., eds. Electronic tagging and tracking in marine fisheries. Dordrecht, The Netherlands: Kluwer Academic Publishers. 237-248.

http://dx.doi.org/10.1007/978-94-017-1402-0_11

Horodysky, A.Z., Kerstetter, D.W., Latour, R.J., and Graves, J.E. 2007. Habitat utilization and vertical movements of white marlin (Tetrapturus albidus) released from commercial and recreational fishing gears in the western North Atlantic Ocean: Inferences from short duration pop-up archival satellite tags. Fisheries Oceanography 16(3):240-256. http://dx.doi.org/10.1111/j.1365-2419.2007.00419.x

Keating, K.A. 1995. Mitigating elevation-induced errors in satellite telemetry locations. Journal of Wildlife Management 59(4):801-808.

http://dx.doi.org/10.2307/3801960

Krueger, C.C., Wilmot, R.L., and Everett, R.J. 1999. Stock origins of Dolly Varden collected from Beaufort Sea coastal sites of Arctic Canada and Alaska. Transactions of the American Fisheries Society 128(1):49-57.

http://dx.doi.org/10.1577/1548-8659(1999)128<0049:SOODVC $>2.0 . \mathrm{CO} ; 2$

Lacroix, G.L. 2013. Population-specific ranges of oceanic migration for adult Atlantic salmon (Salmo salar) documented using pop-up satellite archival tags. Canadian Journal of Fisheries and Aquatic Sciences 70(7):1011-1030. http://dx.doi.org/10.1139/cjfas-2013-0038

- 2014. Large pelagic predators could jeopardize the recovery of endangered Atlantic salmon. Canadian Journal of Fisheries and Aquatic Sciences 71(3):343-350.

http://dx.doi.org/10.1139/cjfas-2013-0458

Lam, C.H., Nielsen, A., and Sibert, J.R. 2008. Improving light and temperature based geolocation by unscented Kalman filtering. Fisheries Research 91(1):15-25.

http://dx.doi.org/10.1016/j.fishres.2007.11.002
Magdanz, J.S., Braem, N.S., Robbins, B.C., and Koster, D.S. 2010. Subsistence harvests in Northwest Alaska, Kivalina and Noatak, 2007. Technical Paper No. 354. Kotzebue: Alaska Department of Fish and Game, Division of Subsistence.

McCart, P.C. 1980. A review of the systematics and ecology of Arctic char, Salvelinus alpinus, in the western Arctic. Canadian Technical Report of Fisheries and Aquatic Sciences 935. 89 p.

Morita, K., Morita, S.H., Fukuwaka, M., and Nagasawa, T. 2009. Offshore Dolly Varden charr (Salvelinus malma) in the North Pacific. Environmental Biology of Fishes 86(4):451 - 456.

http://dx.doi.org/10.1007/s10641-009-9547-7

Musyl, M.K., Domeier, M.L., Nasby-Lucas, N., Brill, R.W., McNaughton, L.M., Swimmer, J.Y., Lutcavage, M.S., Wilson, S.G., Galuardi, B., and Liddle, J.B. 2011. Performance of popup satellite archival tags. Marine Ecology Progress Series 433:1-28.

http://dx.doi.org/10.3354/meps09202

Pedersen, S., and Linn, A., Jr. 2005. Kaktovik 2000-2002 subsistence fishery harvest assessment. Fisheries Resource Monitoring Program, Final Report for Study FIS01-101. Anchorage: U.S. Fish and Wildlife Service, Office of Subsistence Management, Fishery Information Services Division.

R Core Team. 2014. R: A language and environment for statistical computing. Vienna, Austria: R Foundation for Statistical Computing. http://www.R-project.org/

Scanlon, B. 2011. Fishery management report for sport fisheries in the Northwest/North Slope Management Area, 2009. Fishery Management Report No. 11-32. Anchorage: Alaska Department of Fish and Game, Divisions of Sport Fish and Commercial Fisheries.

Seitz, A.C., Wilson, D., Norcross, B.L., and Nielsen, J.L. 2003. Pop-up archival transmitting (PAT) tags: A method to investigate migration and behavior of Pacific halibut Hippoglossus stenolepis in the Gulf of Alaska. Alaska Fishery Research Bulletin 10(2):124-136.

Sibert, J.R., Musyl, M.K., and Brill, R.W. 2003. Horizontal movements of bigeye tuna (Thunnus obesus) near Hawaii determined by Kalman filter analysis of archival tagging data. Fisheries Oceanography 12(3):141-151.

http://dx.doi.org/10.1046/j.1365-2419.2003.00228.x

Thorstad, E.B., Rikardsen, A.H., Alp, A., and Økland, F. 2013. The use of electronic tags in fish research-an overview of fish telemetry methods. Turkish Journal of Fisheries and Aquatic Sciences 13:881-896.

Volkov, A.F., Chuchukalo, V.I., Radchenko, V.I., Efimkin, A.Y., and Kuznetova, N.A. 1996. Summer feeding habits of the Dolly Varden in the Bering Sea. Oceanology 35:827-832.

Yoshihara, H.T. 1972. Monitoring and evaluation of Arctic waters with emphasis on the North Slope drainages. Annual Report of Performance, 1972 - 1973, Study G-III-A, Federal Aid in Sport Fish Restoration, Vol. 14. Juneau: Alaska Department of Fish and Game. 